\title{
Implementation of the Spirituality of Saint Francis of Assisi in the Life of the Brotherhood in Franciscan Missionary Sisters of Assisi Simalingkar B Medan
}

\author{
Ermina Waruwu ${ }^{1}$, Imelda Sianipar ${ }^{2}$ \\ ${ }^{1,2}$ Universitas Prima Indonesia, Indonesia \\ Corresponding Author: Ermina Waruwu
}

\begin{abstract}
Spirituality is a trasendental relationship and the creation of unity relations between nature and humans, the universe and unity between individuals and God. The formulation of the research problem is how to implementation of the Spirituality of Saint Francis of Assisi in the life of the brotherhood in Franciscan Missionary Sisters of Assisi Simalingkar B Medan. The purpose of the study was to explain the findings of the implementation of the spirituality of SFA in the life of the brotherhood in SFMA Simalingkar B Medan. The design of the research used is qualitative research using analytical procedures that produce descriptivequalitative data. The sample technique used to determine the informant is a snowball sampling technique consisting of 10 SFMA sisters. Primary data sources come from interviews, observation and documentation. The results of the study were analyzed using milles and hubberman models were data reduction, data presentation, the drafting of conclusions. Stages of research, namely data transcription, data identification, data classification, data interpretation, data description. The technique used to ensure the level of data validation is triangulation, examination of colleagues, and auditing. The results are SFMA sisters have made Christ the center of living in brotherhood in the community. This brotherhood is turned on by the sabda and is supported by various prayer practices. Brotherhood among the sisters based on the love of the gospel while still prioritizing the attitude of accepting, aware of the similarities between one and the others, namely
\end{abstract}

together with total. Open each other, understand each other and willing to sacrifice. This spirituality implementation is expected to remain maintained because of this spiritual implementation as the basic capital in fulfilling the call as a religious.

Keywords: Spirituality, Saint Francis of Assisi, Brotherhood, Franciscan Missionary Sisters of Assisi

\section{INTRODUCTION}

Spirituality is a form, special and special forms or ways in religious life, kebatinan life or spiritual life. Spirituality is a trasendental relationship and the creation of unity relations between nature and humans, the universe and unity between individuals and God. Religious life is the teachings and practice of Christian sanctity [8]. Spirituality animates the life of the faith of a person who directs the greater perfection and the main concern for Jesus Christ. These spirituality involves all personalities so they can experience and know God[25].

Specifically this study focuses on Franciscan spirituality whose character is Saint Francis. Franciscan spirituality is the science of spiritual life[24] and religious people who are called to support the spirituality of the life of Saint Francis of Assisi (SFA), namely you for everyone. Saint Francis invites everyone who wants to support the way of life of Franciscan by 
making all living things as brothers (be a brother for all). One of the conceenses or monasteries that support the principle of Franciscan is the Franciscan Missionary Sisters of Assisi (SFMA) sisters in Medan, Indonesia. The Constitution of SFMA Simalingkar B Medan in the life of the brotherhood said that the origin, the picture and the fullness of each brotherhood was the work of the Holy Spirit of the love binding between the Father and Putera[19]. A religious in the SFMA tarekat is someone who devotes his life to worship God[4]. Living Hidup Bakti is expected to practice the spirituality of brotherhood in this fellowship in the frame of God's plan. Vita Consecrata's document confirms the life of the brothers in the sense of living with Cintakasih is a clear symbol for the ecclesiastical fellowship and practiced in the brotherhood of SFMA[40]. The book of canonical law emphasizes life of brotherhood which characterizes each tarekat, where all members are united as in one family, especially in Christ $\left[18^{\mathrm{Kan} 602}\right]$.

This age emerges a problem related to the spirituality of religious brotherhood, namely individualism. Individualism is an attitude and acts of rejection that human individuals are internally difficult to connect with others. In addition, the influence of globalization where people tend to be opted against smartphones that inhibit cognitive, emotional, social and spiritual development [36]. In other cases spirituality problems are experienced by those who are sick, for example, sad, shock, desperate, anxious, afraid of death, low self-esteem, decrease in self-perception and this has an impact on the quality of life[32]. This is due to the unavailability of spiritual health servants[37]. In addition, pastoral professional service personnel often lack social support and leadership support so that spirituality is not strong, even though spirituality can be used as an individual's discovery so as not to experience spiritual issues[28].

Another problem of the spiritual realm is to lose the meaning of life, obsessive, alienated, afraid of death, afraid of sin, does not focus on God[22]. Therefore spiritual implementation can be a hope and support to improve depression and strengthen the sense of welfare[35]. Another other issue is a case of irregularities, corruption, lies, unethical behavior. For example, the failure of Enron in the 2000s who performed the forgery of financial statements carried out by their own management. Based on this case, Spirituality at the Workplace is applied where the principle of work is not just fulfilling worldly needs[29]. Spirituality can also be used as a strategy for relieving stress at work[28]. These spiritualiats in an effort to find life meanings, harmony between beliefs and values in the group. So, if someone does not experience spiritual issues, he is getting worse and living in harmony in his life[23].

This research is important so that there is an increase in welfare and quality of life, life goals, sensitivity to the environment[29]. This is evidenced in the results of Niko 2019 research that $91 \%$ believes that spiritual health is equally important with physical health[37]. Spirituality with confidence to the Most High Power has a positive impact on welfare and health so that individuals have a clear life purpose[21].

The formulation of the research problem is how to implementation of the spirituality of SFA in the life of the brotherhood in SFMA Simalingkar B Medan. The purpose of the study was to explain the findings of the implementation of the spirituality of SFA in the life of the brotherhood in SFMA Simalingkar B Medan.

\section{LITERATURE REVIEW Spirituality of Brotherhood}

The word spirituality comes from the Latin Spiritus word which means spirit, soul or enthusiasm. Spirituality comes from the word 'spirit' which means spirit, spirit, soul, holy[39]. Spirituality is a trasendental relationship and the creation of unity 
relations between nature and humans, the universe and unity between individuals and God[22]. This unity of relations can make healthy people prosperous even if the relatives of this fellowship are maintained can be experienced in life after death[6]. Spirituality is a power power that moves a person to develop its relations with the holy[28] which refers to God, divine[2]. Aam said that this awareness was called as a force that exceeded the spiritual aspects, wholeness and relations with the universe[15]. So, spirituality as a way for someone in finding a stable living principle[29]. The more quality stability if you carry out spiritual activities such as present in the church, commitment to religion, convinced with religion adopted so that it experiences happiness[14].

Therefore, spirituality is the basis of life of brotherhood in a community. Humans become brothers and others. Jesus himself said, "You are all brothers, your father is only one, which is in heaven"[20]. Said brother referring to the most dasariah and inseparable unity because it came from the Father who was one and the same $\left[20^{1 \text { Cor }}\right.$ $12: 12-13]$.

\section{Spirituality of Saint Francis of Assisi (SFA)}

SFA was so clear to dictate his will, "This is how God bestowed me, brother Francis, to start repenting"[41] Saint Francis is full aware that his call comes from God. Saint Francis said in a will with the terms of conversion. Living in repentance according to him is a life journey according to the gospel.

Francisis is a unique and interesting person, the church found the special charisma, called francisan spirituality. Pope Pius XII further stated, the teachings of Franciscan lead to God's holy, great and beyond all, well really good. The Holy God is experienced as love. So the strong pressure of Franciscan spirituality lies in the fact that God is love[41].

\section{Pecalphicality of SFA Spirituality}

Franciscan religious life stands above four pillars of value. The main value is: praying, repentance, dome and poverty[j], appreciation of these values will bring out the typical Franciscan in the brotherhood, namely the spirit of the pleasure, the spirit of excitement, enthusiasm to become a missionary of peace and justice.

Followers Saint Francis held repentance in brotherhood, awareness of existence as brothers and sisters for all. In other words, the typical Franciscan brotherhood is the Christian life center, brotherhood that is turned on by the sabda, brotherhood supported by prayer, the brotherhood is based on the love of evangelical, mutual acceptance, the similarity of the total members of the group, open and mutual understanding and also willing to sacrifice.

\section{SFA Doctrine and Message}

Saint Francis is one of the figures known as people who have cosmic souls. He was able to brothers with other creation creatures, with the universe and its contents. Saint Francis found that creation creatures reflect out 'God is covert, power and his eternal god $\left(20^{\text {Roma } 1: 19}\right)$. Basically it is because God has given the responsibility of creation to humans to maintain his relationship with God, his neighbor and his environment[10]. If humans obey this responsibility, humans survived and if not then humanity experiences an overall havoc[7].

From the corner of the creation of Saint Francis, he looked at his existence as 'there were with others' not 'above the others'. This was confirmed by Boff through Buce's writing which emphasized ecological ethics, namely creation as a partious part of the cosmic family. The principle of the integrity in question is that there are no members who harmonize each other, oppress, oppress the earth as a shared home, female sisters and mothers who care and feed[31]. Thus the environmental 
sustainability is a core practice and spirituality values[11].

\section{Brotherhood in Franciscan Missionary Sisters of Assisi (SFMA)}

This tarekat was born in Assisi in 1702[19] and in Indonesia, SFMA was opened in 2004 by two sisters (Sister Susanna Park and Sister Regin) from South Korea who came as a missionary. In 2009 SFMA had its own monastery at Simalingkar-B, Medan. The brotherhood of the SFMA sisters came from brotherhood that had been lived by Saint Francis of Assisi. The principle of brotherhood emphasized by Saint Francis is egaliters where human relations with humans and other creatures are rebuilt because humans have received God's gift inclusive[3].

\section{RESEARCH METHODS Research Design}

The design of the research used is qualitative research using analytical procedures that produce descriptivequalitative data, in the form of words and sentences compiled logically, relevant to the method and are prepared based on the results of research obtained from the field. This research is described not in the form of numbers or formulas because it is qualitative research[26]. The descriptive method used in the study means it describes or describes the object or the results of the study, namely implementation of the Spirituality of Saint Francis of Assisi in the life of the brotherhood in Franciscan Missionary Sisters of Assisi Simalingkar B Medan.

\section{Research Informants}

This research informant is a sister in the Franciscan Missionary Sisters of Assisi (SFMA) Simalingkar B Medan. The sample technique used to determine the informant is a snowball sampling technique. Sampling is the selection of samples based on certain characteristics that are considered to have relevance to the characteristics of the population that have been known previously[28]. The informants were selected and considered reliably in providing information about 10 people consisting of junior sisters 5 (five) people, sister novices 3 (three) people, sister postulants 2 (two) people.

\section{Data Source and Analysis}

The data source comes from the results of research interviews collected from informants. Primary data sources come from interviews, observation and documentation about implementation of the Spirituality of Saint Francis of Assisi in the life of the brotherhood in Franciscan Missionary Sisters of Assisi Simalingkar B Medan. Library research of reference sources is a form of research that uses library facilities by examining theoretical discussions from various books, articles, and scientific works related to writing [27]. Research is prepared with open interview guidelines, direct observation and factual photo documentation. The results of the study were analyzed using milles and hubberman models[33], were data reduction, data presentation, the drafting of conclusions. Stages of research, namely data transcription, data identification, data classification, data interpretation, data description. The technique used to ensure the level of data validation is triangulation, examination of colleagues, and auditing basicly on research data.

\section{RESULT AND DISCUSSION Result}

The results of the research on the implementation of the spirituality of brotherhood in the Franciscan Missionary Sisters of Assisi (SFMA) monastery that have been found in the field are described in the following table. 
Ermina Waruwu et.al. Implementation of the Spirituality of Saint Francis of Assisi in the life of the brotherhood in Franciscan Missionary Sisters of Assisi Simalingkar B Medan

Table 1: Implementation of the Spirituality of the Brotherhood of Saint Francis at SFMA Monastery, Medan-Indonesia

\begin{tabular}{|c|c|c|c|}
\hline No. & $\begin{array}{l}\text { The Spirituality of the } \\
\text { Brotherhood of Saint Francis }\end{array}$ & Informant Code & $\begin{array}{l}\text { Implementation of the Spirituality of the Brotherhood of Saint } \\
\text { Francis at SFMA Monastery, Medan-Indonesia }\end{array}$ \\
\hline 1 & $\begin{array}{l}\text { Christ the Center of Living in } \\
\text { Brotherhood }\end{array}$ & $\begin{array}{l}\text { TS1, TS3, TS4, N1, } \\
\text { N2, N3, P1, P2 }\end{array}$ & $\begin{array}{l}\text { - The attitude of simplicity is not to use goods excessively } \\
\text { - The attitude of the purity of the liver is to establish good } \\
\text { communication between one another } \\
\text { - Self-sacrifice in life together, give themselves in every activity } \\
\text { according to the community schedule }\end{array}$ \\
\hline 2 & $\begin{array}{l}\text { Brotherhood is Turned on by } \\
\text { the Sabda }\end{array}$ & $\begin{array}{l}\text { TS1, TS2, TS3, TS4, } \\
\text { N1, N2, P1, P2 }\end{array}$ & $\begin{array}{ll}- & \text { Enthusiastic in listening to each other } \\
\text { - } & \text { Help each other in life together in the community }\end{array}$ \\
\hline 3 & $\begin{array}{l}\text { Brotherhood Supported by } \\
\text { Prayer }\end{array}$ & $\begin{array}{l}\text { TS1, TS2, TS3, TS4, } \\
\text { N1, N2, N3, P1, P2 }\end{array}$ & $\begin{array}{l}\text { - Liven in the celebration of the Eucharist, Daily worship, } \\
\text { meditation, monthly recollection and Lectio Divina } \\
\text { - Carry out the obligation to investigate God's words together in the } \\
\text { community. } \\
\text { - } \\
\text { - } \begin{array}{l}\text { Eacher activities are carried out with enthusiasm on schedule } \\
\text { community }\end{array}\end{array}$ \\
\hline 4 & $\begin{array}{l}\text { Brotherhood That is Based on } \\
\text { the Love of the Gospel }\end{array}$ & $\begin{array}{l}\text { TS1, TS2, TS3, TS4, } \\
\text { N1, N2, N3, P1, P2 }\end{array}$ & $\begin{array}{l}\text { - Intricate with everyone means not discriminating } \\
\text { - } \quad \text { Complement each other if there are shortcomings of fellow } \\
\text { members } \\
\text { - } \quad \begin{array}{l}\text { Building friendly relations means being able to complement each } \\
\text { other in every difference }\end{array} \\
\text { - Prioritizing others means being able to prioritize others in the } \\
\text { community }\end{array}$ \\
\hline 5 & Accept Each Other & $\begin{array}{l}\text { TS1, TS2, TS3, TS4, } \\
\mathrm{N} 1, \mathrm{~N} 2, \mathrm{~N} 3, \mathrm{P} 1, \mathrm{P} 2\end{array}$ & $\begin{array}{l}\text { - Helpful and mutual support means being able to unite, holding } \\
\text { hands in life together } \\
\text { - Learning and mutual respect for mutual differences in the } \\
\text { community } \\
\text { - Adults to overcome a problem meaning that someone is able to } \\
\text { rebuild damaged communication with each other in the } \\
\text { community }\end{array}$ \\
\hline 6 & $\begin{array}{l}\text { Total Similarity Group } \\
\text { Members }\end{array}$ & $\begin{array}{l}\text { TS1, TS2, TS3, TS4, } \\
\mathrm{N} 1, \mathrm{~N} 2, \mathrm{~N} 3, \mathrm{P} 1, \mathrm{P} 2\end{array}$ & $\begin{array}{l}\text { - All of them serve even though rights and obligations in the } \\
\text { community are not all the same } \\
\text { - All of them have duties and responsibilities according to roles and } \\
\text { professions }\end{array}$ \\
\hline 7 & $\begin{array}{l}\text { Open and Mutually } \\
\text { Understand Each Other }\end{array}$ & $\begin{array}{l}\text { TS1, TS2, TS3, TS4, } \\
\mathrm{N} 1, \mathrm{~N} 2, \mathrm{~N} 3, \mathrm{P} 1, \mathrm{P} 2\end{array}$ & $\begin{array}{l}\text { - Honestly, namely expressing each other's needs for each person in } \\
\text { the community } \\
\text { - } \quad \text { Welcoming other new people who want to join the community }\end{array}$ \\
\hline 8 & Willing to Sacrifice & $\begin{array}{l}\text { TS1, TS2, TS3, TS4, } \\
\mathrm{N} 1, \mathrm{~N} 2, \mathrm{~N} 3, \mathrm{P} 1, \mathrm{P} 2\end{array}$ & $\begin{array}{l}\text { - Willing to give themselves in every activity in the community. } \\
\text { For example, want to help each other work with fellow } \\
\text { community members } \\
\text { Willing to sacrifice both time and energy in carrying out every } \\
\text { activity in the community }\end{array}$ \\
\hline
\end{tabular}

\section{DISCUSSION}

The fundamental needs needed by individuals are spiritual. Spiritual aspects can provide motivation for individuals in making good changes, harmony and alignment of individuals with the outside world[34]. This spiritual development was obtained by the beginning of his family where parents as a role model[23]. This spiritual activity is the basic capital in fulfilling a call as a religious. This study becomes more interesting because women who apply them. Because, spiritual for women is the path of sanctity of life and altruism that is used as a set of values[17]. Thus, spiritual has a positive impact on emotional and interpersonal health[30] so that someone experiences joy[16].
Below is explained the results of research on the implementation of the spirituality of life of brotherhood in the SFMA monastery which is based on the spirituality of Saint Francis, among others, among others.

First, Christ is the center of life of the brotherhood. Christ as the center of human life is applied in real life such as making simplicity as a lifestyle, meaning not to use goods excessively. This simplicity is carried out by SFMA sisters who choose the normal life, namely not having attachment to worldly matters. In other words, SFMA spirituality is spirituality centered on Christ and lifestyle empowered by the Holy Spirit[36].

If humans make Christ as the center of life of the brotherhood, the purity of the 
heart is characteristic. An individual who is pure his heart makes God a source and center of his life and has a healthy body health. The purity of the liver is also marked by the individual relationship with divine so that it can increase happiness and stress decreases[14]. In other words, the spiritual dimension can be used by SFMA as an antidote to negative influences such as stress, the feeling is not happy can even strengthen human relations with God firmly[5].

Second, brotherhood is turned on by the Sabda. The basic authentic brotherhood is the Word. The word meant is the Word of God who is always heard every day through the Bible reading activities. Brotherhood which is turned on by the Sabda is also marked by mutual helping together in the community. Because, no human can live alone. This adarry leads to the realization of spiritual dimensions such as believers to the Word of God, so the meaning and objectives of life are clear, internal resources and harmony with the environment and all humans[15].

Third, brotherhood is supported by prayer. Prayer as a basis, life source and hope in carrying out authentic brotherhood spirituality[22]. Pray with other people and prayed for others is a component in the spiritual needs that are most needed including also sick brothers[32]. The highest needs of individuals are carrying out religious rituals, prayers, worship or meditation[34]. Prayer shows an attitude of recognition that all the successes and achievements obtained are a gift from God[29]. Various types of prayer that can be done are prayers in the celebration of the Eucharist, or other relevant activities such as Lectio Divina, Daily worship, meditation, recollection or other spiritual activities. Prayer can create a positive illusion, eliminate individual concerns about negative thoughts, deaths, curses and spiritual void[38]. Prayer can affect security in the community because if community members carry out spiritual activities, the community is automatically safely spiritually [1].

Fourth, brotherhood that is based on love for evangelical love. The basic brotherhood is love. The love that is meant is love that does not distinguish both tribes, groups, religions, skin color, taste and so on. The love applied in brotherhood is universal love, namely in God there is no difference, all humans are God's creation. The teachings of this love can be obtained through spirituality experience in Christianity because religion is an entity that combines human cognition, emotions, motivation, and other behavioral aspects [28]. Finally, the experience of individual spirituality with the gospel in Jesus Christ is the core shaft in Christian spirituality[36].

Fifth, accept each other. The implementation of life in the community is characterized by a unified attitude, holding hands in facing challenges even though every person is not the same. Precisely the difference is used as an opportunity for mutual learning and mutual respect for differences. Because, spirituality can affect the management of problems, stress, spirituality gives self-strength, adaptability, has calmness and can even nourish individual physiological aspects[32].

Sixth, the similarity of the total group members. The similarity of the total group members in the community is both serving in love. Especially for service with poor people is the holy duties of all humans who are also as a basis for the spirituality and the foundation of social responsibility [13]. Each person in the community both has duties, work and responsibility in accordance with his profession and provide services to people without pressure[12]. If spiritual activities are carried out properly, routinely at certain times, it can create individuals with good behavior, both with themselves and with people around them even though each different role in the form of services is different also[1].

Seventh, open and mutually understand. Openness in life together appears in honest attitudes and actions in 
expressing personal needs in the community. Brotherhood in life together is carried out by upholding spiritual and humanitarian values, treating each other and compassionate with each other[27].

Eighth, willing to sacrifice. The willingness of sacrificing as the realization of the values of spirituality approved by aspects of honesty, motivation, tolerance, patience, compassion, goodness, pleasure, hope and love[22]. If someone applies these values to automatically obtain spiritual health, it is increasingly able to love God, yourself, organs without giving up and the spirit of doing virtue in faith, hope, affection, patience and customization[6]. In other words, the size of the spirituality is someone who has or is looking for meaning, life objectives and trasension harmony and having connectedness with higher strength [9].

\section{CONCLUSION}

The implementation of the Spirituality of Saint Francis of Assisi (SFA) in the life of the brotherhood in Franciscan Missionary Sisters of Assisi (SFMA) Simalingkar B Medan Medan has been implemented properly. Based on the results and research findings, the sisters at the Medan-Indonesia FMA monastery have implemented the spirituality of life brotherhood, among others, sisters have made Christ the center of living in the brotherhood in the community. This brotherhood is turned on by the sabda and is supported by various prayer practices. The brotherhood among the sisters is based on the love of the gospel while still prioritizing the attitude of accepting each other by remaining aware of the similarities between one and the others, namely together with total. Open to each other, understanding and willing to sacrifice has been applied by the sisters at this SFMA monastery.

\section{Acknowledgement: None}

Conflict of Interest: None

\section{Source of Funding: None}

\section{REFERENCES}

1. Abdullah, Zaki., Jubba, Hasse. (2020). Pengaruh Religiusitas dan Kegiatan Spiritual terhadap Persepsi Tingkat Keamanan di Indonesia. Jurnal Studi Agama dan Masyarakat, Vol 16 (01).

2. An, C. H., West, A. D., Sandage, S. J., \& Bell, C. A. (2018). Relational Spirituality, Mature Alterity, and Spiritual Service among Ministry Leaders: An Empirical Study. Pastoral Psychology. doi:10.1007/s11089-018-0846-9.

3. Alakas, B., \& Bulger, D. (2020). Francis's animal brotherhood in Thomas of Celano's Vita Prima. Postmedieval, 11(1), 23-32. doi:10.1057/s41280-020-00153-0.

4. Ayuban, Elias L. (2008). Topik-topik Kanonik Berkenaan dengan Tradisi Kehidupan Religius Medan: Bina Media Perintis. page 3.

5. Binti Ahmat, Andang Andaiyani., Bin Ambotang, Abdul Said. (2020). Pengaruh KecerdasanEmosi, Kecerdasan Spiritual dan Persekitaran Keluarga Terhadap Stres Akademik Murid Sekolah Menengah. Malaysian Journal of Social Sciences and Humanities (MJSSH), Volume 5 (5).

6. Buju, S. (2019). Clinical Approach of Spiritual Illnesses: Eastern Christian Spirituality and Cognitive Behavioral Therapy. Pastoral Psychology. doi:10.1007/s11089-019-00874-5.

7. Claude-Hélène Mayer, Wolfgang $M$. George, Elmar Nass. (2019). "Care for the Common Home": Responses to Pope Francis's Encyclical Letter. Journal of Religion and Health https://doi.org/ 10.1007/s10943-019-00957-w.

8. Cletus Groenen, (2011). Spiritualitas Fransiskan. Yogyakarta: Cipanas, page 6.

9. Ferreira-Valente, A., Sharmam, S., Torres, S., Smothers, Z., Pais-Ribeiro, J., Abbott, J. H., \& Jensen, M. P. (2019). Does Religiosity/Spirituality Play a Role in Function, Pain-Related Beliefs, and Coping in Patients with Chronic Pain? A Systematic Review. Journal of Religion and Health. doi:10.1007/s10943-019-00914-7.

10. Freyer, B., Aversano-Dearborn, V., Winkler, G., Leipold, S., Haidl, H., Brand, K. W., Wallnig, T. (2018). Is there a Relation Between Ecological Practices and 
Spirituality? The Case of Benedictine Monasteries. Journal of Agricultural and Environmental Ethics, 31(5), 559-582. doi:10.1007/s10806-018-9745-4.

11. Freyer, B., Aversano-Dearborn, V., Winkler, G., Leipold, S., Haidl, H., Brand, K. W., Wallnig, T. (2018). Is there a Relation Between Ecological Practices and Spirituality? The Case of Benedictine Monasteries. Journal of Agricultural and Environmental Ethics, 31(5), 559-582. doi:10.1007/s10806-018-9745-4.

12. Frick, E., Büssing, A., Baumann, K., Weig, W., \& Jacobs, C. (2015). Do Self-efficacy Expectation and Spirituality Provide a Buffer Against Stress-Associated Impairment of Health? A Comprehensive Analysis of the German Pastoral Ministry Study. Journal of Religion and Health, 55(2), 448-468. doi:10.1007/s10943-0150040-7.

13. Ghosh, S., \& Mukherjee, S. (2020). The Relevance of Spirituality and Corporate Social Responsibility in Management Education: Insights from Classical Indian Wisdom. Philosophy of Management. doi:10.1007/s40926-020-00141-1.

14. Holder, M. D., Coleman, B., \& Wallace, J. M. (2008). Spirituality, Religiousness, and Happiness in Children Aged 8-12 Years. Journal of Happiness Studies, 11(2), 131150. doi:10.1007/s10902-008-9126-1.

15. Imadudin, Aam. (2017). Spiritualitas dalam Konteks Konseling. Journal Of Innovative Counseling: Theory, Practise \& Research 1 (1).

16. Jones, A. E., \& Elliott, M. (2016). Examining Social Desirability in Measures of Religion and Spirituality Using the Bogus Pipeline. Review of Religious Research, 59(1), 47-64. doi:10.1007/s13644-0160261-6.

17. Lazar, A. (2013). Lay Conceptualizations of Spirituality and Religiousness Among Jewish Israeli Men and Women. Review of Religious Research, 56(1), 107-128. doi:10.1007/s13644-013-0130-5.

18. Konferensi Waligereja Indonesia. (2019). Kitab Hukum Kanonik (Codex Iuris Canonici,). Diterjemahkan oleh Sekretariat KWI . Jakarta: Obor, p 192.

19. Konstitusi Suster Fransiskanes Misionaris dari Assisi. 2014. Konstitusi Suster-Suster Fransiskanes Misionaris dari Assisi. Assisi, page 61 .
20. Lembaga Alkitab Indonesia. 2017. Alkitab Deuterokanonika. Jakarta: Lembaga Alkitab Indonesia.

21. Maglione, J.L., Neville, K. Servant Leadership and Spirituality Among Undergraduate and Graduate Nursing Students. J Relig Health (2021). https://doi.org/10.1007/s10943-021-013119.

22. MahdiNejad, J.-D., Azemati, H., \& Sadeghi Habibabad, A. (2019). Religion and Spirituality: Mental Health Arbitrage in the Body of Mosques Architecture. Journal of Religion and Health. doi:10.1007/s10943019-00949-w.

23. Mangestuti, Retno (2017). Pengembangan Spiritualitas Remaja: Mengapa Remaja Laki-laki Lebih Memerlukan Dukungan Keluarga dalam Pengembangan Spiritualitas. Jurnal Psikoislamika Vol 14 (1).

24. Marpaung, Manangar C. (2008). Introduksi Spiritualitas Fransiskan. Medan: Bina Media Perintis, 2008. page 3.

25. Melé, D., \& Fontrodona, J. (2016). Christian Ethics and Spirituality in Leading Business Organizations: Editorial Introduction. Journal of Business Ethics, 145(4), 671-679. doi:10.1007/s10551-0163323-3.

26. Moleong, Lexy. 2010. Metodologi Penelitian Kualitatif. Bandung: Rosda Karya. pag 326-342.

27. Pandiangan, Saut Maruli Tua. (2018). Analisis Faktor-faktor yang Mempengaruhi Penawaran Tenaga Kerja Lanjut Usia di Kota Medan. Tesis. Medan: Fakultas Ekonomi dan Bisnis, Program Studi Ilmu Ekonomi, Universitas Sumatera Utara. http://repositori.usu.ac.id/bitstream/handle/1 23456789/10033/167018013.pdf?sequence= $1 \&$ isAllowed $=y$.

28. Pandiangan, Saut Maruli Tua, Rujiman, Rahmanta, Tanjung, Indra I., Darus, Muhammad Dhio, \& Ismawan, Agus. (2018). An Analysis on the Factors which Influence Offering the Elderly as Workers in Medan. IOSR Journal of Humanities and Social Science (IOSR-JHSS), 23(10), 76-79. DOI:10.9790/0837-2310087679.

http://www.iosrjournals.org/iosrjhss/papers/Vol.\%2023\%20Issue10/Version $-8 / \mathrm{K} 2310087679 . p d f$.

29. Paul, M., Jena, L.K. \& Sahoo, K. Workplace. (2020). Spirituality and 
Workforce Agility: A Psychological Exploration Among Teaching Professionals. J Relig Health 59, 135-153 https://doi.org/ 10.1007/s10943-019-00918-3.

30. Perera, C. K., Pandey, R., \& Srivastava, A. K. (2018). Role of Religion and Spirituality in Stress Management Among Nurses. Psychological Studies, 63(2), 187-199. doi:10.1007/s12646-018-0454-x.

31. Putro, Taufik Achmat Dwi., Riyono, Bagus. (2019). Islamic Work Ethic: Nilai-nilai Spiritualitas Islam pada PT. Andromeda. Psikoislamedia Jurnal Psikologi Vol 4 (2).

32. Ramakrishnan, P., Baccari, A., Ramachandran, U., Ahmed, S. F., \& Koenig, H. G. (2017). Teachers' and Parents' Perspectives on a Curricular Subject of "Religion and Spirituality" for Indian Schools: A Pilot Study Toward School Mental Health Program". Journal of Religion and Health, 57(4), 1330-1349. doi:10.1007/s10943-017-0474-1.

33. Ranboki, Buce A. (2017). Menemukan Teologi Leonardo Boff dalam Ensiklik Paus Fransiskus Laudato Si. Indonesian Journal Of Theology 5 (1).

34. Rosyadi, Imron., Kusbaryanto., Yuniarti, Falasifah Ani. (2019). Literature Review Aspek Spiritualitas/Religiusitas dan Perawatan Berbasis Spiritual/Religius Pada Pasien Cancer. Jurnal Kesehatan Karya Husada, Vol. 7 (1).

35. Sugiono. (2014). Metode Penelitian Pendidikan-Pendekatan Kuantitaf, Kualitatif, dan R\&D. Bandung: Alfabeta. p 32.

36. Sujana, Elva., Fatimah, Sari., Hidayati, Nur Oktavia. (2017). Kebutuhan Spiritual Keluarga Dengan Anak Penyakit Kronis. Jurnal Pendidikan Keperawatan Indonesia. 3 (1).

37. Smith, S. T., Blanchard, J., Kools, S., \& Butler, D. (2016). Reconnecting to Spirituality: Christian-Identified
Adolescents and Emerging Adult Young Men's Journey from Diagnosis of HIV to Coping. Journal of Religion and Health, 56(1), 188-204. doi:10.1007/s10943-0160245-4.

38. Shim, J. Y. (2019). Christian Spirituality and Smartphone Addiction in Adolescents: A Comparison of High-Risk, Potential-Risk, and Normal Control Groups. Journal of Religion and Health. doi:10.1007/s10943018-00751-0.

39. Sutrisno, Niko., Swasti, Keksi Girinda., Mulyono, Wastu Adi. (2019). Pengetahuan, Persepsi dan Sikap Perawat RSUD Arjawinangun tentang Asuhan Keperawatan Spiritual. Journal of Bionursing Vol 1 (1).

40. Skrzypińska, K. (2016). The Boundaries of Woman's Spirituality in the BeliefsSpirituality-Religiousness (B-S-R) Model: A Third Perspective-Beliefs as a Cognitive Basis. Journal of Religion and Health, 56(5), 1583-1599. doi:10.1007/s10943-0160334-4.

41. Syamsul Jamil. (2008). Kamus Terbaru Bahasa Indonesia. 2008. Surabaya: Reality Publisher, p, 603.

42. Vita Consecrata. Hidup Bakti. (2016). diterjemahkan oleh R. Hardawirjana. Bogor: Grafika Mardi Yuana, p, 46.

43. Wasiat Santo Fransiskus. (2008). Karyakarya Fransiskus dari Asisi. Yogyakarta: Kanisius. Sekretariat Keluarga Fransiskan Indonesia (SEKAFI), p, 16-18.

How to cite this article: Waruwu E, Sianipar I. Implementation of the Spirituality of Saint Francis of Assisi in the life of the brotherhood in Franciscan Missionary Sisters of Assisi Simalingkar B Medan. Galore International Journal of Applied Sciences \& Humanities. 2021; 5(3): 26-34. DOI: https://doi.org/ 10.52403/gijash.20210704 